\title{
メタクリル樹脂の破壊*
}

$$
\text { 黒部 利 次** 若 島 久 男*** }
$$

\section{Fracture of Polymethyl Methacrylate}

\author{
by \\ Toshiji Kurobe and Hisao Wakashima \\ (Faculty of Technology, Kanazawa University, Kanazawa)
}

\begin{abstract}
Polymethyl methacrylate specimens were fractured by the static bending, and the speed of the crack propagation was measured by the speed of breaking of the electro-conductive coatings on the surface of the specimens. The rate of crack propagation speed obtained by our method is found to be greater than that which has been obtained by any other investigator.

It is found that the fracture morphology is roughly divided into three main classes: (1) the glassy fracture surface containing a number of geometric figures resembling parabolas, (2) the fracture surface having the semicircular "ribs or scallops" of great roughness, and (3) the fracture surface of the greatest roughness at low temperature. It seems that the concentric scallops observed on the fracture surface of the notchless specimens have been produced by the dilatational wave based on the stress release as the crack spreads over the plate.

(Received Nov. 11, 1966)
\end{abstract}

\section{1 緒言}

メタクリル樹脂（熱可塑性二次元直鎖状高分子）の 破壊に関する研究は，すでに多くの人たちによってな されているが，まだその破壞のメカニズムを解くまで には至ってないようである。ささらに，結晶性樹脂や熱 硬化性三次元網状高分子を含むプラスチック材料全体 の破壊に関する組織的な研究は, 理論的にも実験的に もあまり進んでいない，乙れは高分子材料がまだ比較 的新しい材料であるにもかかわらず，その種類が豊富 なとと，それにその性質が多様であるために，プラス チック材料の破壊に関してまだ統一的見解が得られな いためであらら之思われる。しかし，プラスチック材 料か媇しい工業材料として普及するにつけ，プラスチ ック材料の機械的強度とか破壊の機構などをもっと基 礎的な立場から理解するととが必要と思われる。

プラスチック材料の破壊に関する研究は J.A. Kies のメタクリル樹脂の破面に関する研究か端緒と思われ る. その後, F. Zandman 注荷重速度による影響を, J. Wolock et al. は分子量による影響を調べそれぞれ 大きな影響を及ぼすととがわかった。ささらに，分子配 向, 温度, クラックなどの影響についても調べられて いる。

* 原槁受理 昭和41年11月11日

** 正会員 金冯大学工学部 金冯市小立野 2 丁目

*** 金冯大学工学部 金沢市小立野 2 丁目
試料を破壊する方法も目的によっていろいろあるが， 最も一般的なものは引張試験による方法である，J.J.

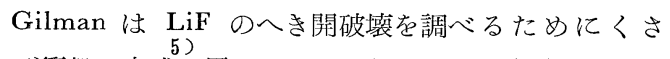
び衝撃の方式を用いている。われわれの実験では高速 破壊を得るためと, 破䘫進行速度をあるる程度変えると とを意図して，試料を静的に湾曲させて破壊させた。 また，破壊に及ぼす温度の効果を調べるため，試料温

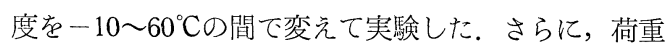
の破面に及ぼす影響を各種顕微鏡を用いて詳しく調べ た. そしててれらの研究から，メタクリル樹脂の高速 破壊に関する破壊機構を考察した。

\section{2 実 験 装 置}

試料は市販のメタクリル樹脂（三菱レイヨン，アク リライト板）を用い, 試料を Fig. 1 亿示すように, 試料の両端を支持し，中央に荷重を加えて静的に曲げ て破阹した。荷重は油圧ジャッキで加え，その測定は prooving ring を用い, ring の変形は差動トランス Aで測った。 ての prooving ringは1 $\mathrm{t}$ の荷重に耐 うるようになっている。 また, 試料台と加圧棒の間隔 を差動トランスBで測って試料のたわみとした，両差 動トランスの出力は変位測定器を経てXYレコーダの 入力端子に接続し, 荷重一たわみ曲線を得た.

破壊に及ぼす温度の影響を調べるために, 試料温度 を常温付近で多少変化させるととができるようにした， すなわち，低温度はアルミボックスにドライアイスを 


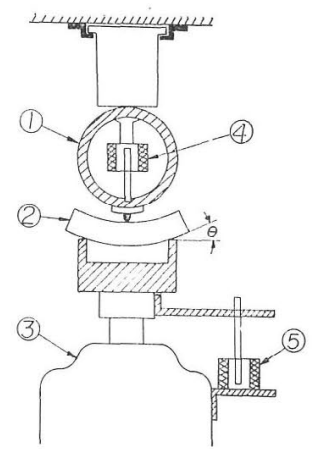

(1) Prooving ring

(2) Specimen

(4) Differential transformer A

(3) Hydraulic jack

(5) Differential transformer $B$

Fig. 1. Schematic diagram of the experimental apparatus.

そう入し，高温度は薄い銅板で作ったボックスに雲団 をアラルダイトでその内外に張り，その上に $0.1 \mathrm{~mm} \phi$ のニクロム線を巻き，そのジュール熱によって得るよ うにした。

破榬進行速度を变えるため, 試料に，(a)ノッチナシ， (b) $\mathrm{V}$ ノッチ，(c)丸ノッチをやすりでつけた。 以後 $\mathrm{a}$ 試

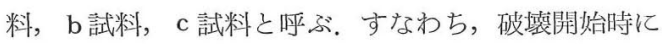
おいて，試料にたくわえられる弾性エネルギを变える ことにより，破噮進行速度を変えるとと趋図した。 $\mathrm{V}$ ノッチの切込角は $60^{\circ}$ で, 切込深さは約 $4 \mathrm{~mm}$, 丸 ノッチは約 $1.5 \mathrm{~mm} R$ の半円である。試料の大ささは, $\mathrm{a}$ は 100 (長さ) $\times 20$ (幅) $\times 10$ (厚さ) $\mathrm{mm} ， \mathrm{~b} ， \mathrm{c}$ は100 $\times 20 \times 8 \mathrm{~mm}$ である.

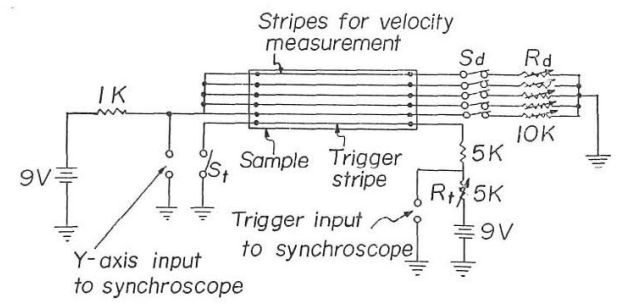

Fig. 2. Circuits used for measuring crack velocity.

破壊進行速度の測定には，あらかじめ試料表面に破 壊進行方向に直角に数条の導電線を貼布しておく．と れら導電線は互いに並列に連結され，Fig. 2 に示す 破填進行速度測定回路を構成する。破猿が烚まれば 試料表面の導電線は順次切断するが，そのつど導電 線両端の電圧は恋化するから，この電圧変化をシンク ロスコープに描かせば Fig. 3 に示すような段階状の 図形が得られ，とれからクラックの進行速度が計算で きる。導電線としては試料表面に導電性塗料をカラス 口で0.6〜0.8 mm 愊に塗布し充分乾燥させた。このよ

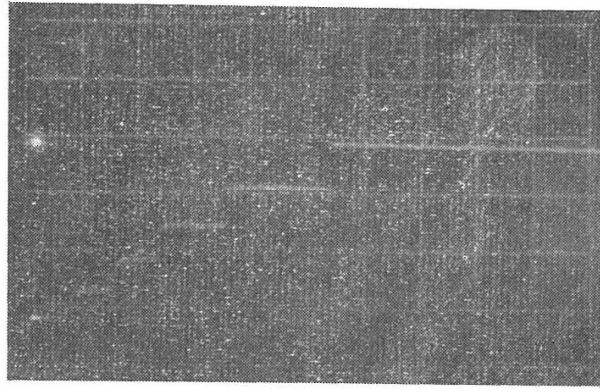

Fig. 3. Oscillogram of fracture (Sweep time $10 \mu \mathrm{sec} /$ div.).

らにして得られた導雷線とアクリル樹脂との密着は充 分によく，試料の群性変形や破壤時の衝揧で試料表面 からはく離するようなととはまったくなかった。導電 線の線間隔は約 $2 \mathrm{~mm}$, 線抵抗は $10^{2} \sim 10^{3}(\Omega)$ であ る. Fig. 2 において $R_{d}$ は破境前にシンクロスコープ のフレを調整するための抵㧤で， $R_{t}$ はトリガーの駆 動点を調整するための抵抗である。スイッチ $S_{d}, S_{t}$ は 破壊前に回路が正常に動作するかいなかをチェックす るためのものである。Fig. 4 は装置全体の写真である。

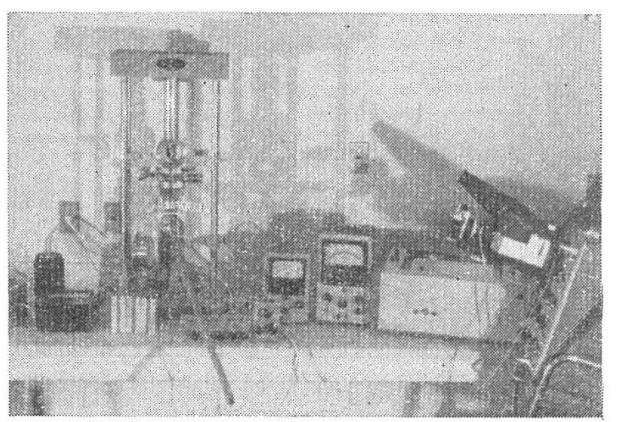

Fig. 4. General view of the experimental device.

\section{3 実験結果および考察}

\section{1 破壊進行速度の測定}

Fig. 5 は Fig. 1 亿示卞A，B両差動トランスの破 壊閒始までに描く荷重ーたわみ曲線の一例である。乙

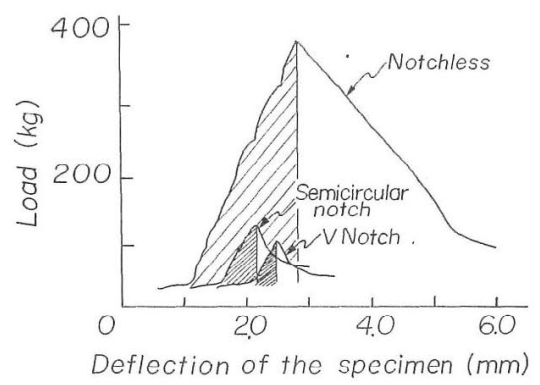

Fig. 5. Relation between load and deflection of the specimen. 
Table I. Relation between temperature and energy and crack velocity.

\begin{tabular}{|c|c|c|c|c|c|c|c|c|c|}
\hline \multirow[b]{2}{*}{$\begin{array}{c}\text { Temp } \\
\left({ }^{\circ} \mathrm{C}\right)\end{array}$} & \multicolumn{3}{|c|}{ Notchless } & \multicolumn{3}{|c|}{$\mathrm{V} \cdot$ notch } & \multicolumn{2}{|c|}{ Semicircular notch } & $\square \sim$ \\
\hline & $\underset{(\mathrm{erg}) \times 10^{7}}{\text { Energy }}$ & $\begin{array}{l}\text { Average crack } \\
\text { velocity } V_{c}^{*} \\
(\mathrm{~m} / \mathrm{sec})\end{array}$ & $\begin{array}{c}\text { Ratio of } V_{s} * * \\
\text { to } V_{c} \\
\left(V_{c} / V_{s}\right)\end{array}$ & $\underset{(\mathrm{erg}) \times 10^{6}}{\text { Energy }}$ & $\begin{array}{c}\text { Average crack } \\
\text { velocity } V_{c} \\
(\mathrm{~m} / \mathrm{sec})\end{array}$ & $\begin{array}{c}\text { Ratio of } V_{s} \\
\text { to } V_{c} \\
\left(V_{c} / V_{s}\right)\end{array}$ & $\underset{(\mathrm{erg}) \times 10^{6}}{\text { Energy }}$ & $\begin{array}{c}\text { Average crack } \\
\text { velocity } V_{c} \\
(\mathrm{~m} / \mathrm{sec})\end{array}$ & $\begin{array}{c}\text { Ratio of } V_{s} \\
\text { to } V_{c} \\
\left(V_{c} / V_{s}\right)\end{array}$ \\
\hline-10 & 562 & 770 & 0.82 & 103 & 310 & 0.33 & 1.13 & 310 & 0.33 \\
\hline 0 & 415 & 450 & 048 & 1.91 & 230 & 024 & 2.25 & 310 & 0.33 \\
\hline 10 & 5.52 & 450 & 048 & 091 & 200 & 021 & 2.30 & 300 & 0.32 \\
\hline 20 & 5.33 & 410 & 0.44 & 1.78 & 250 & 0.27 & 3.42 & 380 & 0.40 \\
\hline 30 & 904 & 470 & 050 & 3.02 & 230 & 0.24 & 3.29 & 240 & 0.26 \\
\hline 40 & 9.37 & 580 & 062 & 278 & 200 & 021 & 5.29 & 270 & 0.29 \\
\hline 50 & 922 & 560 & 0.60 & 278 & 220 & 023 & 404 & 280 & 030 \\
\hline 60 & 452 & 460 & 049 & 2.41 & 180 & 019 & 3.23 & 210 & 022 \\
\hline
\end{tabular}

* The averaged value of the propagation speed of the brittle crack between the first line (Trigger line) and the final leading w'ire

** $V_{s}=(F / \rho)^{1 / 2}$, here $E\left(109 \times 10^{4} \mathrm{~kg} / \mathrm{cm}^{2}\right)$ is Young's modulus of the specimen, $\left(1.18 \mathrm{~g} / \mathrm{cm}^{3}\right)$ is density of $1 \mathrm{t}$

の実験で求めた荷重一たわみ曲線の囲む面積（斜線部 分）は破壊直前までに試料に加えられるエネルギを表 わすが，乙れは一般に試料にたくわえられる弾性エネ ルギおよび塑性変形のエネルギの総和を示すものであ る.しかし， $60^{\circ} \mathrm{C}$ 以下では塑性変形のエネルギはほと んど無視できる。したがって，乙のエネルギは $60^{\circ} \mathrm{C}$ 以 下ではだいたい弾性エネルギとみなしてよい. Table I は破壊開始までに試料に加えられるエネルギとクラッ クの平均進行速度が温度とともにどのように変わるか を各試料について示したものである. 試料にたくわえ られるエネルギと温度との関係をグラフで表わすと Fig. 6 のようになる。一般に温度が高くなるにつれて エネルギは徐々に増すが，だいたい $40 〜 50^{\circ} \mathrm{C}$ ところ で一定の值となる。

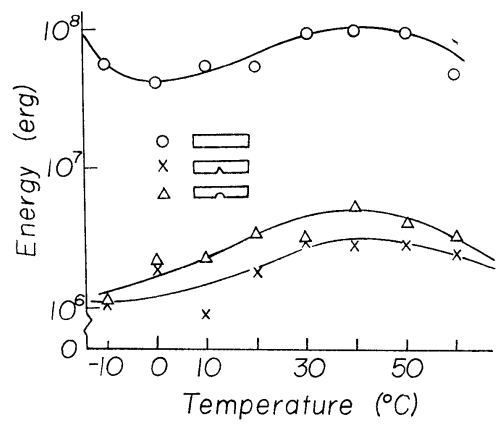

Fig. 6. Relation between energy and temperature.

試料の破壊進行速度は試料表面に貼布された導電性 塗料の切断速度から求めるととができる. Fig. 3 亿示 す例から求めたクラックの進行に伴う破断速度の変化 はFig. 7 のうになる。一般にクラックの伝ぱ速度は 破壊の開始とともに急激に増大し, 破壊起点から数

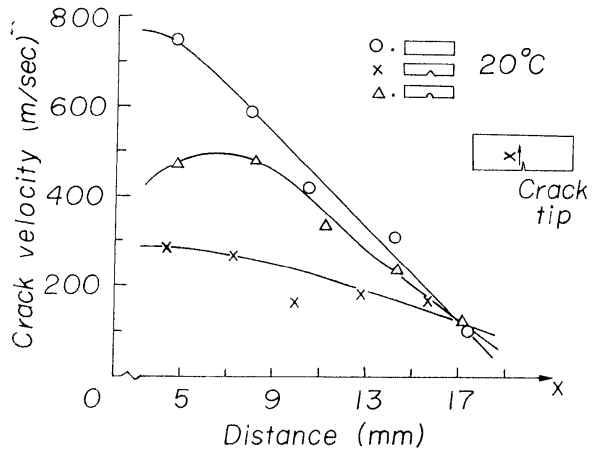

Fig. 7. Relation between crack propagation velocity and distance.

$\mathrm{mm}$ のところで最高速度 $V_{\max }$ になり，その後ゆるや かに減少する．TableIにおいては，てのように場所的 に変化する速度の平均值を示して各材料の破壊速度の めやすとした．てのようにして求められたクラックの 伝ぱ速度が，一般にかなり速いことは破断後試料の破 片が高速で飛散するととからも理解できる。すなわち， 破壊が始まる直前までに外力のなしたエネルギ $U$ は 破壊進行中に外力のなす仕事 $P$ と武版が完全に破断 した後の破面の表面エネルギ $S$ と試片の運動エネル ギ $T$ に変わるものと考えられる.

$$
U=T+S+P
$$

しかし，一般に破壊は高速であるから第 3 項を省略す るととができる。幅 $b$, 厚さ $t$ で支点間距離 $l$ のはり の中央に集中荷重 $W$ を加えた場合の中央部のたわみ を $y$ とすると，てのたわみを生じさせるに必要な仕 事 $U$ は塑性変形を無視すれば,

$$
U=\frac{W^{2} l^{3}}{8 E b t^{3}}
$$

で与えられる，ここに，Eは材料のヤング率である。 
次に, 破面の表面エネルギ $S$ は $\gamma$ 比表面エネルギ とすれば，

$$
S=2 \gamma b t
$$

で与光られる。また破片の運動面工ネルギ $T$ は，

$$
T=\frac{1}{2} \rho b t l V_{0}{ }^{2}
$$

である。ここに， $\rho$ は武料の密度である。したがって， 以上の諸最老エネルギ式(1)に入れ整理す扎ば，破断後 の破片の飛散速度 $V_{0}$ は次のようになる。

$$
V_{0}=\frac{2 t y}{l^{2}} V_{S}\left[1-\frac{l^{3} \gamma}{E t^{2} y^{2}}\right]^{1 / 2}
$$

ここに, $V_{S}=(E / \rho)^{1 / 2}$ は音速である. $\gamma$ は J.P. Berry によれば， $1.40 \times 10^{5} \mathrm{erg} / \mathrm{cm}^{2}$ の程度であるから，括弧 内の第 2 項は 1 に比べて小さい值となり省狢すると, 破断後試片が飛散する速さ $V_{0}$ は近似的に，

$$
V_{0}=\frac{2 b y}{l^{2}} V_{S}
$$

で与えられる。破断直前に試片にたくわえられる弾性 エネルギ座 $5.33 \times 10^{7} \mathrm{erg}$ とすればV。は $14.4 \mathrm{~m} / \mathrm{sec}$ となる。ささら片，クラックが試片を貫通する間は支点 に㧈いて武片が水平となす角（Fig. $10 \theta$ ) は不変に 保たれるものと仮定すれば（クラックが武片在貫通す る時間は約 $50 \mu \mathrm{sec}$ 程度であるから)，クラックの伝 ぱ速度は $300 \mathrm{~m} / \mathrm{sec}$ 程度になり, 奏験值にコンパラブ ルな值が得られる。 Table I そおいてb，c試料の夕 ラック伝ぱ速度が $\mathrm{a}$ 武料のそ扎比べて小さいのは以 レ゙の理由によるものである。

一方，㵷藤らはシャルピー型くさび衝撃試験機で $110 \mathrm{~m} / \mathrm{sec}$ ○破稂進行速度在得ている。羊た，White

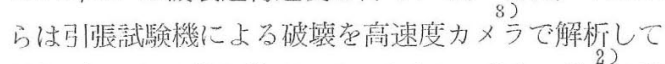
$100 \mathrm{~m} / \mathrm{sec}$ 小る值老得ている。さらに, Schardinは引 張武験で 374 $515 \mathrm{~m} / \mathrm{sec}$ の值右それぞれ得ている。 いまとれらの值と Bending 法でわれわれが得た值を 比へてみると，Bending 法で得られる破鿬進行速度 はかなり大きいととがわかる。さらに，ての兮法では 試料の形状定変えるととにより, ある程度破偯進行速 度を制御することがてきる。

Fig. 8 に破猿進行速度に及ぼす埧度の影響在示可。 $\mathrm{a}$ 試料では温垬が呫くなるにつれてりラックの伝ぱ速 度は徐々に增し 40 ～ $50^{\circ} \mathrm{C}$ 付近でだいだい一定の值とな る。引張試験によれば $40^{\circ} \mathrm{C}$ 以上では破断は分離破面か らせん断破損に移行するという Newman et al. の結 果からもいいうるように，との温度の前後で破壊機構 になんらかの変化があるものと思わ机る。

\section{$3 \cdot 2$ 破断面の観察}

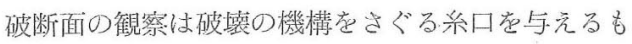
のとして重要視されている，破面の炕学的観察にはア ルミニウ々在破面に真空蒸着し，金属顕微鏡，顕微干 涉計などで観察した。電子顕微鏡用試料は直接破面に

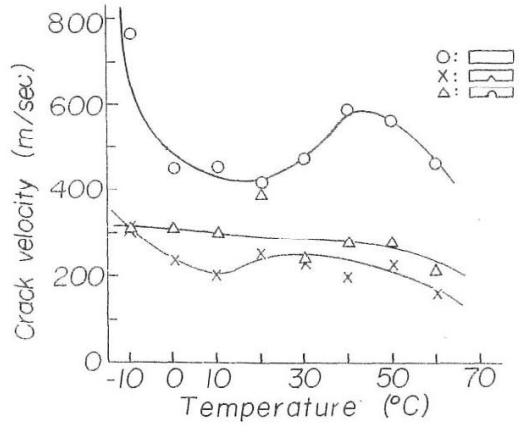

Fig. 8. Relation between crack velocity $V_{\mathrm{c}}$ and temperature.

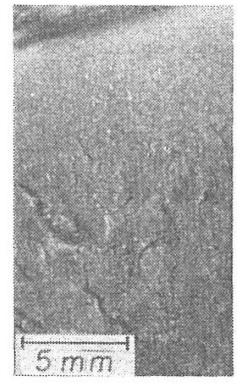

$-10^{\circ} \mathrm{C}$

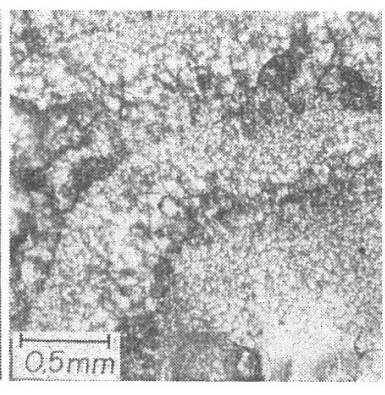

$20^{\circ} \mathrm{C}$
Fig. 9. Microphotograph of the fracture surface of the specimen (a).

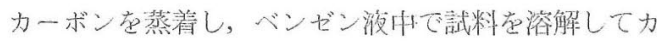
一ボンレプリカを得た。

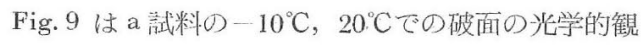

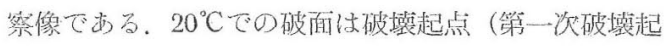

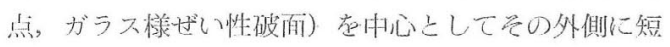
いパラボラ状 Trace が放射状に広がり，さらにその 外側には破壞起点在中心とする巨視的な同心归状粗鬆 破面(Ribs or scallops) が羿められる。粗鬆破面の外 側はふたたびパラボラ領域となり，てれらが幾何学的 周期性存もって繰り返している。パラ゙ラ模樣が現わ れる成因はパラボラの焦点がーつの佊堿起点（第二次 破猿起点）となって，そこから発生した放射状に広が る制机の破壊進行線が第一次破垶起点から発生した制 わの破填進行線と互いにぶつかり合い干泚し合ら結果 生ずる軌跡とみなすととができる。温度芷降げていっ て，おおよそ００以下の温度になると，破断面はFig. $9\left(-10^{\circ} \mathrm{C}\right.$ の破面) に示すように念激に变化する。す な方ち，非常に荒れた粗嘻破面となる。Fig. 10(b)は20 `Cでの破面のパラボラ頭部の第二次破壊起点近傍の電 子顕微鏡与具である。(a)は第一次破壤起点の電子顕题 鏡马真で光学顕微鏡てただ平坦と感しられるるの部分 にも微視的にはかなりの起伏があるととがわかる。

$\mathrm{b} ， \mathrm{c}$ 各試料の破断面はほとんど同じ破面である。 これらの破面には同心円状粗鬆破面は認められない。 


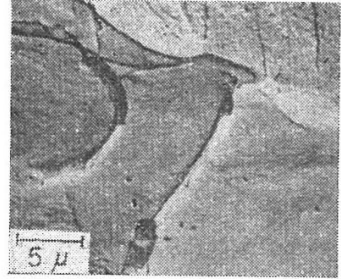

(a)

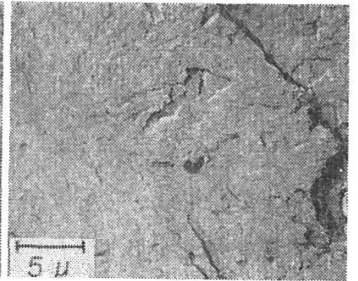

(b)
Fig. 10. Electronmicrophotograph of the fracture surface of the specimen (a).

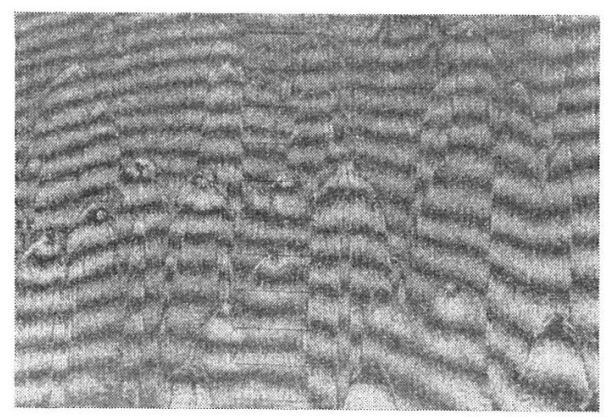

Fig. 11. Observation of the fracture surface of the specimen (b), (c) by the interferrometer.

後述するように，乙れは破塤開始までに試料にたくわ えられる弾性エネルギが少なく, 破壊の進行に伴う弾 性エネルギの開放に基づく弾性振動の振愊が小さいた めと思われる。Fig. 11は顕徽干渉計でその破面の起伏 の状態を調べたものである。波長は $0.66(\mu)$, スケール は $0.1 \mathrm{~mm}$ である。パラボラ内部で干涉じまが湾曲し ていることから，ハララボラ内部は $0.3 \mu$ 程度の凸ある いは山の曲率を持った面になっているものと思われる。 a 試料に特に顕著に認められる同心円状粗鬆破面の 成因は, クラックの進行に伴い試料内部の弾性応力が 解放され弾性波定生ずるため, 站料内の応力状態が周 期的に変わるためと考光られる。そこで武料にバーク ライトケージを張ってクラックの進行に伴って生ずる

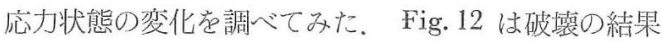
得られたオシログラムである。 Fig. 13 は方の破面で

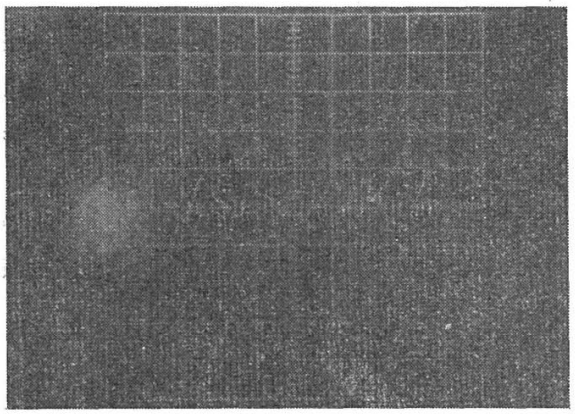

Fig. 12. Oscillogram of showing the vibration of the specimen by fracture.

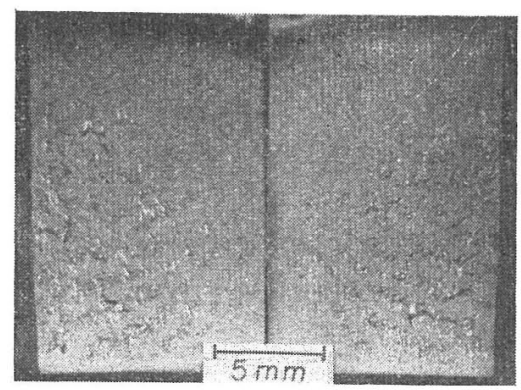

Fig. 13. Fracture surface of the specimen which show the vibration in Fig. 12.

ある、とれらの結果在比較するとオシログラムに現わ れた振動数と破面の scallops 数はだいたい一致して いる。 この結果，同心円状粗鬆破面は破垶時の試料の 振動の結果生ずるものと思われる。

前述した破壞進行速度の分布䤚線 (Fig. 7) 之破面 に現われた模様を結びつけて考觉ると, 制れの始った 直後の破欀進行速度の比較的扔そい領域ではパラボラ

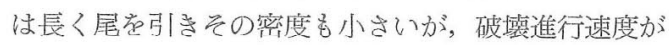
增すにつれてパラボラの尾は短くなりその密度を增す。 同心円状粗鬆破面ではパラボラ密度は最も高く, こと では各破圗起点(第二次破淕起点)からほぼ形に進行 する破堎進行線が互いにぶつかり無数のポリゴンを形 作っている。.上上のととからパラボラ密度の最も高い

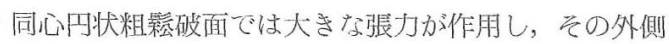
のパラボラ密度の小さい領域では比較的小さな㖘力し 汃作用していないるのと思わ机る。このようにクラッ クの進行に伴って生ずる応力状態の変化(応力の大小) に応じて破面に幾何学的周期性模様力現われるもの之

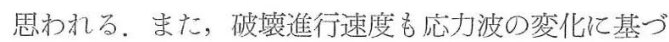
く張力の大小に応して遲速を繰り返しながら割れが伝 ぱするものと思われる。

\section{4 結論}

メタクリル樹脂の高速破䏅における諸現象を調べる ために武料を静的に湾曲させて破壤し，クラックの伝 ぱ速度を試料表面に貼布した導線の切断速度から求め た、試料にはあらかじめノッチ施し, ある程度クラ ックの伝ぱ速度を变化させ，さらに破壊に及ぽす温度 の影響を調べるために試料温度をー $10 \sim 60^{\circ} \mathrm{C}$ の間で变 光て実験した。得られた結果在要約すると，

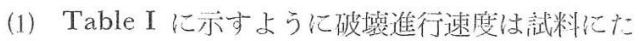
々わ兄られるエネルギにだいたい比例して変わる、 試料の破㯖進行速度は切灭きのある b， C 試料のそれ。 に比べてはるかに大きい，一般に，クラックの伝ば速

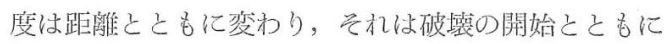
急激僧大し, 破墇起点から数 $\mathrm{mm}$ のとろで最高速 度 $V_{\max }$ になり，その後りるやが減少する。 
（2）破壊進行速度は a 試料では温度が高くなるにつ れて増長するが， $40^{\circ} \mathrm{C}$ 前後でだいたい一定の值になる。 これは Newman et al. の引張試験の結果に対応し, この温度領域で破壊機構になんらかの変化があるもの と思われる。

（3）くさび衝撃試験や引張試験などで得られたてれ までの值に比べて，Bending法でわれわれが得た破壊 進行速度の值はかなり大きいととがわかった。さらに， 試料の形状を変えれば破壊進行速度をある程度制御で きる。

(4) メタクリル樹脂の fracture morphology は 3 とおりに大別できることがわかった。すすおち，Fig. 9 亿示す $-10^{\circ} \mathrm{C}$ の粗鬆破面と $20^{\circ} \mathrm{C}$ 貝がら模様の破面, それに Fig. 10 に示すパラボラ模様のなめらかな破面 の 3 とおりである.

（5） a 試料に多く認められる同心円状粗鬆破面は破 壊時の試料の振動の結果生ずるものと思われる.

(6) b， c 試料の破面を顕微干渉計で調べた結果, パラボラ内部は $0.3 \mu$ 程度の凸あるいは凹の曲率を持
った面になっているものと思われる。

(昭和 41 年 4 月 1 日 応用物理学会第 13 回講宙会にて講蒋)

\section{参考 文 献}

1) Kies, J.A., A.M. Sullivan, and G.R. Irwin, J. Appl. Phys., 21, 716 (1950).

2) Averbach, B.L., et al., "Fracture" (1959) Technol. Press of M.I.T., and J. Wiley \& Sons, New York.

3) Rosen, B., "Fracture Processes in Polymeric Solids" (1964) Inter Science Publishers, New York.

4) Newman, B., G.R. Irwin, and J. Wolock, J. Appl. Phys., 29, No. 1, 49 (1958).

5) Gilman, J.J., C. Knudsen, and W.P. Walsh, J. Appl. Phys., 29, 601 (1958).

6) Berry, J.P., J. Appl. Phys., 34, No. 1, 62 (1963).

7) 斎藤勝政, 三品博達, 第13回熱硬化性樹脂講演討 論会要旨，p. 87 (1963).

8) Bueche, A.M., and A.V. White, J. Appl. Phys., 27, 980 (1956).

\title{
Elasticity (Tensor, Dyadic and Engineering Approaches)
}

\author{
Pei Chi Chou and Nicholas J. Pagano 著
}

(A 5 判，290ページ，3500円，1967年 2 月，D. Van Nostrand Company，Inc. 発行)

本書は大学学部学生および大学院学生用の教科書と して書かれた弾性力学の本である. 線形弾性の理論を, 工学的手法, 直交テンソルを用いた方法, およびベク トルを用いた方法の 3 方向より取り扱っているのが本 書の最も大きな特徵である，各方法はそれぞれ独自の 特長をもっており，したがって，゙れぞれの方法を 関連づけて学ぶことにより学生は弾性力学に 対して より完成されたイメージをつかむととができるであろ う。しかし以上の特徵のため, 具体的に取り技ってい る内容は二次限の問題と标じりの問題までであるが, テンソルやベクトルダイアドを用いる場合の基礎式は 充分与えられているから，さらに複雑な問題への応用 は可能である，テンソルの性質等について数学的㛜密 さに欠ける点はあるが，教科書として使われる以上ぺ
一ジ数に制限がありいたし方なく，かなりの参考文献 をあげることによって補っている。

終わりに各章の題目をあげておく. (1) Analysis of stress, (2) Strain and displacement, (3) Stress strain relations, (4) Formulation of problems in elasticity, (5) Two-dimensional problems, (6) Torsıon of cylindrical bars, (7) Energy methods, (8) Cartesian tensor notation, (9) Stress tensor, (10) Strain, d1splacement, and the governing equations of elasticity, (11) Vector and dyadic notation in elasticity, (12) Orthogonal curvilinear coordinates, (13) Displacement functions and stress functions.

(京都大学工学部機械 柴田俊忍) 